\title{
A estratégia de acomodação na ditadura brasileira e a influência da cultura política
}

\author{
La estrategia de acomodación en la dictadura brasileña y la \\ influencia de la cultura política
}

\author{
Rodrigo Patto Sá Motta \\ Universidade Federal de Minas Gerais, Brasil \\ rodrigopsamotta@gmail.com
}

\begin{abstract}
Resumo
0 artigo apresenta reflexões teóricas sobre os comportamentos sociais diante das ditaduras recentes e sobre as estratégias de dominação dos regimes autoritários, com ênfase para o caso brasileiro. Dialogando com a historiografia dedicada ao fascismo europeu dos anos 1930/40, o texto propõe uma tipologia (adesão, acomodação e resistência) capaz de iluminar as relações entre os meios universitários e a ditadura militar brasileira. Além disso, argumenta-se que acomodação é parte da cultura política brasileira e que esse caminho de ação explica algumas características da peculiar transição pós-ditatorial, bem como certos impasses do momento atual.
\end{abstract}

\section{Palavras chave}

Ditadura; cultura política; acomodação; repressão; resistência

\section{Resumen}

El artículo presenta reflexiones teóricas sobre los comportamientos sociales durante las dictaduras recientes y sobre las estrategias de dominación de los regimenes autoritarios, con énfasis en el caso brasileño. Doalogando con la historiografía dedicada al fascismo europeo de los años 30/40, el texto propone una tipología (adhesión, acomodación y resistencia) capaz de iluminar las relaciones entre los medios universitarios y la dictadura militar brasilera. Se argumenta que la acomodación es parte de la cultura política brasileña y que ese camino de acción explica algunas de las características de la pecualiar transición pos dictatorial así como ciertos impasses del momento actual.

Palabras clave

Dictadura; cultura política; acomodación; represión; resistencia 


\section{A estratégia de acomodação na ditadura brasileira e a influência da cultura política}

A proposta do artigo é apresentar o quadro teórico desenvolvido no livro As universidades e o regime militar: modernização autoritária e cultura política brasileira ${ }^{1}$, em que estudei as políticas universitárias da ditadura e seus impactos na comunidade acadêmica. Mais do que divulgar a discussão teórica em que se baseou o livro, a intenção é reelabora-la a partir de outros enfoques e leituras realizadas depois da publicação do trabalho. Interessa, em especial, discutir o aporte que a historiografia sobre a ocupação nazista da Europa pode trazer ao debate teórico sobre os comportamentos sociais diante de estados autoritários, chamando atenção para o cuidado que é necessário para nos apropriarmos dela. Essa questão foi abordada sumariamente no livro, mas é retomada agora com mais profundidade graças a temporada de trabalho na França que permitiu pesquisar melhor a bibliografia. ${ }^{2}$ Em suma, a ideia é contribuir para os estudos sobre as estratégias de poder e de legitimação da ditadura brasileira, e igualmente para as pesquisas dedicadas aos comportamentos sociais diante do autoritarismo. Quem sabe estas reflexões serão úteis, também, para análises comparativas envolvendo outros países que viveram situação semelhante.

Um pressuposto básico para esta análise é que devem ser evitadas interpretações simplistas sobre as ditaduras, pois elas impedem a percepção da complexidade das estratégias de dominação estatal. Afinal, mesmo em situação de ocupação militar e uso agudo da violência, como na Europa dos anos 1930/40, os aparatos estatais buscaram apoio de partes da população através de meios mais suaves de governo. Na verdade, essa discussão implica qualquer forma de Estado. Há uma tradição de pensamento ligada a autores como N. Maquiavel, M. Weber e A. Gramsci que aponta o caráter duplo da dominação estatal, baseada simultaneamente em coerção e consenso. Porém, o retorno aos clássicos implicaria percurso teórico demasiado longo para o escopo deste texto, por isso vamos nos restringir às estratégias de dominação dos Estados autoritários do século XX, com ênfase no Brasil e Cone Sul.

Voltar os olhos para a historiografia dedicada ao caso europeu importa não apenas porque ela inspirou novas análises sobre as ditaduras do Cone Sul, mas também devido à sua apropriação por atores políticos latino-americanos. Com efeito, antes de existir uma historiografia consolidada sobre a Europa fascista os agentes políticos brasileiros já se apropriavam de conceitos produzidos do outro lado do Atlântico. A utilização do par antitético resistência x colaboração para designar os comportamentos diante da ditadura de 1964 foi quase imediata ao evento. Como se sabe, essa conceituação derivou do domínio nazista na Europa, expressando visão dicotômica sobre as atitudes das populações submetidas ao poder dos conquistadores alemães e de seus aliados. Integrada à cultura da

\footnotetext{
${ }^{1}$ Rodrigo Patto Sá Motta. As universidades e o regime militar: modernização autoritária e cultura política brasileira, Rio de Janeiro, Jorge Zahar, 2014.

${ }^{2}$ Entre janeiro e junho de 2016 fui professor visitante do IHEAL, ocupando a Cátedra Simón Bolivar. Agradeço a Olivier Compagnon a sugestão de consultar o trabalho de Philippe Burrin.
} 


\section{Rodrigo Patto Sá Motta}

esquerda mundial, tal conceituação foi aplicada ao Brasil pós-64 por grupos que se imaginavam diante de nova experiência fascista. Com isso, os eventos do golpe poderiam ser inscritos em categorias compreensíveis para a esquerda, com a vantagem de atribuir aos golpistas brasileiros o rótulo fascista.

No entanto, as coisas não eram tão simples. Havia semelhanças com o contexto dos anos 1930-40, já que o anticomunismo era a língua franca da direita e no grupo vitorioso em 1964 estavam representados os herdeiros locais do fascismo. Porém, a direita fascista era sócia minoritária do poder e tinha atritos com outros apoiadores do regime militar, de modo que é inconsistente classificar como puramente fascista a ditadura militar pós-1964. Ademais, não houve ocupação por forças estrangeiras, ao contrário da situação europeia nos anos 1940, o que torna o termo "colaboração" inadequado. É mais correto dizer que alguns grupos participaram, apoiaram ou aderiram ao regime militar - que não era força externa nem resultado de derrota militar, mas, uma construção política considerada legítima por setores sociais significativos ${ }^{3}$. Além disso, muitos comportamentos não podem ser classificados nas opções extremas, de modo que reduzir as atitudes diante da ditadura a resistência ou colaboração é simplificação grosseira.

No contexto europeu, a historiografia há muito questiona a redução de todas as situações ao par dicotômico e nessa linha tem nos oferecido sugestões de análise interessantes. Entretanto, há que refletir sobre sua adequação ao contexto dos países latino-americanos, para evitar apropriações mecânicas. Desde os anos 1970 alguns investigadores da ocupação nazista vêm criticando construções mitológicas e visões simplistas sobre o comportamento das populações derrotadas pelos alemães. No caso da França, o trabalho de Robert Paxton (1973) inaugurou uma linha de pesquisas que iria destruir o mito resistencialista. Esse historiador mostrou a profunda colaboração entre as autoridades francesas e as forças de ocupação alemãs, desencadeando uma virada na memória e também na historiografia que estuda o tema. ${ }^{4}$

$\mathrm{Na}$ década seguinte outros historiadores seguiram pela mesma senda, notadamente Henry Rousso, Pierre Laborie, Philippe Burrin e Jacques Semelin ${ }^{5}$. Esses autores confirmaram algumas questões apontadas por Paxton, mas, em certos aspectos, criticaram apropriações da obra daquele historiador que geraram novas versões simplistas. 0 mito de uma maioria resistente ao nazismo (e a seus aliados), com justeza criticado à luz das novas pesquisas, acabou por alimentar um

\footnotetext{
3 Algumas pesquisas de opinião feitas à época revelam esse apoio, embora os números (e sua interpretação) sempre possam ser questionados. Rodrigo Patto Sá Motta. 0 golpe de 1964 e a ditadura nas pesquisas de opinião. Revista Tempo, Niterói, vol. 20, 2014:1-21.

${ }^{4}$ Robert Paxton. La France de Vichy, 1940-44. Paris, Éditions du Seuil, 1974. Efeito semelhante e convergente teve o filme de Marcel Ophuls (Le Chagrin et la Pitie), que foi lançado no mesmo período.

${ }^{5}$ Henry Rousso. Le Syndrome de Vichy. Paris, Éditions du Seuil, 1987; Pierre Laborie. L'Opinion française sous Vichy. Paris, Éditions du Seuil, 1989; Philippe Burrin. La France à l'heure allemande: 1940-1944. Paris, Éditions du Seuil, 1995; Jacques Semelin. Sans armes face à Hitler, la resistance civile en Europe. Payot et Rivages, 1989.
} 


\section{A estratégia de acomodação na ditadura brasileira e a influência da cultura política}

contra mito igualmente simplificador: a maioria teria colaborado com o nazismo. Esse debate, inevitavelmente explosivo, foi acompanhado de inúmeras polêmicas historiográficas, disputas políticas e conflitos de memória ao longo das últimas três décadas, provocando batalhas em torno do revisionismo e da judicialização da memória.

Importa ressaltar que a partir dessas polêmicas foram produzidas análises mais sofisticadas e menos dicotômicas sobre os comportamentos diante dos vencedores nazistas. Nessa linha, destaque-se a contribuição de Pierre Laborie que, ao estudar as flutuações de opinião questionou a versão de que 40 milhões de franceses haviam se transformado, da noite para o dia, de colaboradores em resistentes, de petainistas em gaullistas. Para construir seu argumento ele apontou as ambivalências presentes à época, a complexidade do sentimento attentiste ${ }^{6}$ e as zonas de sombra, propondo que as pessoas poderiam ser, por exemplo, petainistas e resistentes ao mesmo tempo; acreditar que o Marechal Petáin pretendia proteger a França e, simultaneamente, torcer pela vitória dos aliados; e poderiam mostrarse superficialmente de acordo com a nova ordem enquanto escondiam seus pensamentos (às vezes atitudes) rebeldes.

Outro autor a destacar é Philippe Burrin, que utilizou o termo acomodação para expressar as atitudes dos setores da sociedade derrotada que não resistiram aos vitoriosos, preferindo adaptar-se ao novo regime. Partindo do pressuposto de que tal acomodação foi voluntária, seu objetivo foi explicar as diferentes gradações e motivos que a inspiraram, fazendo um amplo estudo com foco em diferentes setores da sociedade francesa, desde políticos a empresários, passando por intelectuais e artistas. Para Burrin, quatro elementos motivaram a acomodação com a ordem nazista: a sensação de constrangimento, o interesse material, a complacência pessoal e a conivência ideológica. Embora se reconheça a qualidade e a contribuição original do seu trabalho, uma das críticas à categoria acomodação de Burrin é que ela não se distingue bem de colaboração. 0 leitor fica em dúvida sobre os limites entre os comportamentos de acomodação e de colaboração, se eles seriam efetivamente duas categorias distintas ou, na essência, o mesmo fenômeno.

Chama a atenção na historiografia dos anos 1980 e 1990 a tendência a relegar a segundo plano as ações de resistência, decerto um desdobramento da recusa ao mito resistencialista. Mesmo em um trabalho que foge a essa tendência, como o de Jacques Semelin (Sans armes face à Hitler, la resistance civile en Europe), o propósito foi enfocar um tipo de resistência não convencional, a chamada resistência civil. De qualquer modo, o autor contribuiu para manter o tema da resistência em debate e propôs uma tipologia mais ampla para classificar

\footnotetext{
6 Uma expressão difícil de traduzir, mas significa que muitas pessoas preferiram esperar os acontecimentos a engajar-se ativamente, mesmo odiando os alemães e repudiando o colaboracionismo. Mas, Laborie argumenta que o atentismo dos franceses se tornou cada vez mais simpático à resistência. Pierre Laborie. L'Opinion française..., Op. Cit., p.313.
} 


\section{Rodrigo Patto Sá Motta}

as atitudes da população civil diante dos ocupantes: colaboração, acomodação ou resistência. ${ }^{7}$

Como foi dito, tais pesquisas têm sido inspiradoras para pensar as relações de dominação e o comportamento político no quadro das ditaduras latinoamericanas. Em especial, elas estimularam a questionar os mitos sobre a resistência e a pesquisar o fenômeno do apoio e do consentimento aos Estados ditatoriais, o que amplia a compreensão sobre as bases sustentadoras do poder autoritário. $^{8}$ No entanto, sua apropriação deve ser cuidadosa devido às já mencionadas diferenças de contexto, pois, além da ausência de ocupação estrangeira, a direita que subiu ao poder no Cone Sul nos anos 1960/70 tinha composição ideológica diferente do bloco fascista dos anos 1940, notadamente devido à influência marcante do liberalismo.

Voltando a atenção para o caso brasileiro, e à pesquisa sobre as universidades sob a ditadura, a proposta foi utilizar a tríade adesão, resistência ou acomodação para classificar as relações entre o Estado autoritário e os meios acadêmico-científicos. Em outras palavras, defende-se que essa tríade resume as principais atitudes da comunidade acadêmica diante da ditadura erigida em 1964. Algumas pessoas e instituições promoveram ações que podem ser classificadas em dois ou nos três tipos, em momentos diferentes ou simultaneamente, de modo que o "ou" em alguns casos foi "e" (por exemplo, resistência e acomodação).

A preferência pelo termo adesão no lugar de colaboração deve-se a razões já apontadas. 0 golpe de 1964 não derivou de derrota e ocupação estrangeira, ainda que o apoio da potência norte-americana tenha sido essencial. Ele foi um levante liderado pelas forças de direita que contou com apoio de parte da sociedade (especialmente nas classes média e alta), em luta contra processo de mudanças sociais de viés esquerdista que estava acontecendo durante o governo de João Goulart. E houve muitas adesões à ditadura no mundo acadêmico, que recrutou ali importantes quadros políticos e técnicos que serviram aos sucessivos governos militares.

Quanto à resistência defende-se o uso da mesma expressão, embora algumas de suas características tenham sido diferentes em relação ao contexto europeu. Mesmo assim, no presente caso também se pode conceituar resistência como conjunto de atos de recusa coletiva ao poder instituído, que podem se

\footnotetext{
${ }^{7}$ Jacques Semelin. Sans armes face à ..., Op. Cit., p.341.

8 O debate historiográfico europeu contribuiu para uma nova pauta de pesquisas no Brasil, como nos trabalhos de Daniel Aarão Reis Filho (Ditadura militar, esquerdas e sociedade. Rio de Janeiro, Zahar, 2000), por exemplo, que mostram os limites do mito da resistência e sua manipulação nas batalhas da memória pós-ditadura. Outra autora importante é Denise Rollemberg, tanto em textos próprios como na obra coletiva A construção social dos regimes autoritários: legitimidade, consenso e consentimento no século XX (Rio de Janeiro, Civilização Brasileira, 2010), que coordenou junto com Samantha Quadrat e reúne textos sobre o Brasil e demais países do Cone Sul. Vale a pena consultar também os textos da seguinte coletânea: Rodrigo Patto Sá Motta (org.) Ditaduras militares: Brasil, Argentina, Chile e Uruguai. Belo Horizonte, Editora da UFMG, 2015.
} 


\section{A estratégia de acomodação na ditadura brasileira e a influência da cultura política}

expressar de diferentes maneiras. ${ }^{9}$ Nos espaços universitários houve inúmeras ações de resistência, na maioria protagonizadas pelos estudantes como passeatas, paralisações de aulas e divulgação de produtos culturais censurados; e também atos mais agudos como as ocupações de edifícios, sem esquecer que muitos estudantes foram recrutados por organizações armadas (embora com atuação fora dos campi).

0 aspecto mais original e polêmico do trabalho foi analisar as estratégias e os jogos de acomodação envolvendo a ditadura e os meios acadêmicos. Comecemos discutindo a peculiaridade do uso do termo acomodação frente à conceituação produzida pela historiografia europeia. Embora na época da produção do livro (As universidades e o regime militar) desconhecesse o trabalho de P. Burrin, as reflexões sobre acomodação partiram de questão semelhante: como se comportaram certos segmentos sociais submetidos a regime autoritário? Porém, acomodação no caso brasileiro tem duas singularidades que implicam conceito diferente. Primeiro, ela integra o repertório da cultura política brasileira, portanto, não é produto de situação autoritária episódica. Segundo, a acomodação não foi somente uma maneira de adaptar-se à ditadura: tratou-se de jogo de mão dupla, que envolvia o Estado e o mundo acadêmico/científico. Voltaremos a esse ponto logo adiante, para esclarecer melhor a ideia.

Faz-se necessário apresentar sumariamente o que se entende por cultura política brasileira e seu elemento chave, a acomodação, antes de abordar sua incidência no período ditatorial. Cultura política seria um conjunto de representações, valores e padrões de comportamento político comuns a determinado grupo, sem que isso signifique qualquer forma de atavismo. 0 campo da política supõe o protagonismo de agentes que fazem escolhas: há sempre margem para a opção entre diferentes caminhos de ação. 0 argumento é que as escolhas podem sofrer a influência da cultura política, que oferece aos agentes alguns padrões de ação já inscritos nas tradições, mais atraentes e viáveis por terem gerado sucesso em ocasiões anteriores. Assim, não há porque supor oposição entre a influência de padrões culturais e a escolha dos agentes políticos. A cultura política indica caminhos e estratégias com maiores chances de sucesso que, por isso, podem tornar-se opções interessantes para os agentes envolvidos. Embora a cultura política implique relações sociais, valores culturais e imaginários estruturados, portanto, bem enraizados na sociedade, isso não significa que mudanças sejam impossíveis. Aliás, a grande crise que o Brasil vive hoje talvez seja um marco para mudanças estruturais na cultura política.

\footnotetext{
${ }^{9}$ Conceituação inspirada em Jacques Semelin. Sans armes face à..., Op. Cit. p.79. Ainda há muito o que debater sobre o significado de resistência no contexto ditatorial brasileiro. A esse respeito conferir os textos de Daniel Aarão Reis Filho. "Ditadura e sociedade: as reconstruções da memória" e Marcelo Ridenti. "Resistência e mistificação da resistência armada contra a ditadura: armadilhas para os pesquisadores” em Daniel Aarão Reis Filho, Marcelo Ridenti, Rodrigo Patto Sá Motta (org.). O golpe e a ditadura militar: quarenta anos depois (1964-2004). Bauru, Edusc, 2004.
} 


\section{Rodrigo Patto Sá Motta}

Há que lembrar alguns precursores do debate sobre a cultura brasileira: G. Freyre, Oliveira Vianna, Sérgio Buarque, J. Honório Rodrigues, R. DaMatta, ensaístas argutos, mas às vezes defensores de posições conservadoras que certamente descarto. Mesmo assim, eles elaboraram insights interessantes para pensar a cultura política brasileira, ao apontar temas como o patrimonialismo, a cordialidade, o paternalismo, o personalismo, a flexibilidade, a ojeriza a conflitos e a busca de integração, e a conciliação. Desse conjunto gostaria de destacar dois elementos: a conciliação e o personalismo. No caso do personalismo, trata-se da primazia dos laços pessoais em detrimento de relações impessoais. Trocando em miúdos, na sua atuação política os brasileiros privilegiariam a fidelidade a laços de parentesco, amizade, compadrio ou patronagem à revelia de normas universais, com baixa adesão a projetos políticos impessoais.

Evidentemente, todos esses elementos estão ligados à sociedade patriarcal e escravista nas origens do Brasil, o que gerou concentração do poder em ínfima elite, restrições de acesso à cultura e educação e ausência de democracia no Estado e nos espaços sociais. 0 fim da escravidão, a República e outros processos de mudança posteriores não lograram romper totalmente com os problemas originais. Seguiram influentes o clientelismo, o elitismo, o patrimonialismo, a frágil identificação dos cidadãos com as instituições (em especial os partidos), o pouco apreço e a escassa participação nos espaços públicos. E também a baixa adesão/respeito às normas institucionais, percebidas como ilegítimas, e a busca de alternativas para driblar o sistema legal. Ressalte-se que a fraca participação popular na política institucional não significa ignorância, ao contrário, por vezes ela revela a percepção de que o universo da "grande" política exclui os setores sociais subalternos.

Aliás, a exclusão política dos setores populares era e é um objetivo permanente dos grupos dominantes, que para esse efeito usaram não apenas a repressão, mas também estratégias sutis de negociação, de conciliação ou acomodação. Nosso argumento é que aí está a origem dos jogos de acomodação, que se tornaram tradicionais e integrados à cultura política. 0 medo dos escravos e o fantasma do haitianismo explicam as estratégias de acomodação política dos grupos dirigentes brasileiros no século XIX, a começar pela peculiar negociação do processo de Independência (com o próprio Estado português, a que se pagou uma indenização), a manutenção da unidade das ex-colônias portuguesas (uma façanha baseada em violência e acordo) e até outras acomodações posteriores, chegando ao processo de criação da República sem povo de 1889. Nas décadas seguintes ocorreram novos jogos de acomodação, inclusive durante a ditadura, como será discutido logo a seguir, e também em anos recentes, como será abordado na conclusão.

Antes de retornar à ditadura mais recente, um último comentário. Os ensaístas que primeiro refletiram sobre o tema tenderam a privilegiar o termo conciliação, enquanto nesta proposta de análise a preferência é por acomodação. As duas expressões têm sentidos próximos e sugerem a ideia de acordos, 


\section{A estratégia de acomodação na ditadura brasileira e a influência da cultura política}

negociações e flexibilidade. Mas há algumas peculiaridades que gostaria de destacar. A preferência por acomodação no lugar de conciliação é porque o primeiro termo permite expressar sentidos mais amplos. A conciliação na tradição brasileira significa o acordo político realizado nas altas esferas do poder, envolvendo os grupos dirigentes do Estado. Acomodação, tal como é utilizada aqui, permite integrar esse sentido e incluir também arranjos realizados em outros espaços sociais e institucionais com envolvimento de outros atores, como acadêmicos, cientistas, intelectuais e produtores culturais. ${ }^{10}$ Como será mostrado adiante, acomodação permite expressar melhor a ideia de que mesmo em uma ditadura houve oportunidades para acomodar intelectuais e acadêmicos do campo oposicionista, em um jogo de mútuas concessões entre Estado e atores sociais. ${ }^{11}$ Portanto, um aspecto importante da acomodação é que ela envolve os dois campos; para o jogo funcionar, há que existir uma via de mão dupla, embora se trate de situações de poder assimétricas.

Voltemos nossos olhos, agora, para o tema das relações entre a ditadura e as universidades. 0 objetivo do trabalho era entender o processo de modernização conservadora/autoritária da ditadura na área do ensino superior e da pesquisa. 0 argumento é que a modernização/reforma das universidades durante a ditadura (que conheceram enorme expansão de quadros e de recursos ${ }^{12}$ ) estava conectada a dois objetivos: a) o sucesso do projeto autoritário, pois a modernização universitária era peça importante nos planos desenvolvimentistas da ditadura; b) a estratégia de acomodação, com a tentativa de seduzir a elite acadêmica/científica por meio do aumento dos investimentos nas universidades e da redução da repressão.

Durante a ditadura militar brasileira, para os dirigentes e demais membros da comunidade universitária houve possibilidades intermediárias entre aderir ou resistir. Muitos procuraram maneiras de se acomodar ao novo sistema de poder, sem que isso significasse, a seus olhos, qualquer compromisso com o regime militar. Pessoas que não desejavam aderir, por não partilhar os valores dominantes, mas que também não tinham intenção de resistir frontalmente ao Estado autoritário - por medo da punição ou por achar inútil -, buscaram estratégias de conviver com ele, inclusive como forma de reduzir os efeitos da repressão. Do seu ponto de vista, tratava-se de explorar possibilidades abertas pelo próprio regime militar, usando-as com o objetivo de atenuar o autoritarismo.

\footnotetext{
10 Eventualmente, o que demandaria outras pesquisas, podemos pensar também em jogos de acomodação capazes de envolver setores populares.

11 Acomodação agrada-me também por sugerir uma interessante imagem metafórica, inspirada no fenômeno geológico.

12 Foram criadas novas universidades públicas, federais e estaduais, e houve grande ampliação dos corpos docente e discente. Ademais, foi criado um programa de dedicação exclusiva para docentes de universidades públicas, houve aumento de salários e do número de bolsas e a implantação de um sistema de pós-graduação.
} 


\section{Rodrigo Patto Sá Motta}

Alguns pesquisadores já notaram a ambiguidade e a ambivalência de certos personagens diante da ditadura. ${ }^{13}$ Entretanto, é necessário perceber que a acomodação, tal como está sendo analisada aqui, implicava via de mão dupla, ou seja, o Estado também era ambíguo. Alguns agentes sociais (no caso, líderes acadêmicos) aceitavam conviver com o regime militar, mas este também precisava fazer concessões, de outro modo o arranjo não seria possível. Do lado dos intelectuais e profissionais da academia, alguns atores aceitavam a convivência com o regime autoritário e repressor, por vezes inclusive ocupando cargos oficiais; do lado do Estado, certos agentes toleravam a presença de intelectuais ideologicamente suspeitos em cargos públicos, bem como arranjos para flexibilizar a repressão. Tratava-se de jogo em que o Estado procurava atrair o intelectual/professor e este precisava moderar suas opiniões e comportamentos. Entretanto, o Estado igualmente cedia ao transigir com os valores do "inimigo" por vezes contrários aos seus - e ao permitir sua circulação, ainda que em versões fracas. A flexibilidade estava presente nos dois lados.

A flexibilidade que possibilitou tais estratégias de acomodação se devia, em parte, à heterogeneidade da base de apoio do regime militar, que contava com alas favoráveis à moderação no uso da violência. Entretanto, foi fundamental a influência da cultura política brasileira. Os atores aceitavam colocar em prática essas estratégias porque elas faziam parte do repertório à disposição, com bons resultados em situações anteriores. Por exemplo, durante a ditadura do Estado Novo, regime igualmente anticomunista, o governo também tolerou a presença de intelectuais de esquerda no cenário público, alguns a seu serviço direto ou indireto. ${ }^{14}$

Graças à estratégia de acomodação, as iniciativas repressivas às vezes foram suavizadas por meios indiretos, subterfúgios, negociações, arranjos, protelação burocrática. 0 funcionamento dessas estratégias geralmente envolvia o estabelecimento de compromissos pessoais, elemento também integrante do repertório da cultura brasileira. Por um lado, a motivação para aceitar acordos decorria da presença de laços entre os agentes envolvidos, ligações que para muitos superavam a fidelidade a preceitos formais. De outro lado, a lealdade pessoal era indispensável para o sucesso de acordos informais, construídos à revelia das normas. Esse tipo de situação nem sempre foi viável, porque certos agentes não se mostravam inclinados a compromissos, ou porque, obviamente, o regime não estava disposto a tolerar algumas transgressões e alguns inimigos. Ainda assim, chama atenção o número de casos em que se tentaram estratégias de acomodação, muitas vezes com sucesso.

\footnotetext{
13 Daniel Aarão Reis Filho. Ditadura militar, esquerdas... e Denise Rollemberg "As trincheiras da memória. A Associação Brasileira de Imprensa e a ditadura (1964-1974)". In Denise Rollemberg e Samantha Quadrat, A construção social dos regimes autoritários..., Op. Cit., p.97-144.

${ }^{14}$ Aqui vale lembrar os trabalhos de Sérgio Miceli (Intelectuais à brasileira. São Paulo, Companhia das Letras, 2001) sobre "cooptação" de intelectuais pelo Estado nas primeiras décadas do século XX. No entanto, a perspectiva teórica adotada neste trabalho é diferente, baseada no conceito de acomodação.
} 


\section{A estratégia de acomodação na ditadura brasileira e a influência da cultura política}

Vários intelectuais perseguidos tinham contatos pessoais em posições de poder, a que poderiam recorrer nas horas difíceis: um tio general; uma esposa parente de governador ou de um deputado federal; um amigo de infância que se tornara agente do SNI (Serviço Nacional de Informações); um primo que tinha amizade estreita com influente general da reserva; um pai amigo de juízes importantes; um parente com boas relações com o diretor do DOPS (Departamento de Ordem Política e Social); um amigo capaz de mobilizar um bispo - entre outros exemplos colhidos na pesquisa. Cerca de metade dos entrevistados (em um total de 50) para o livro relatou algum episódio do gênero, envolvendo a si mesmos ou terceiros. Era natural e conforme aos costumes do país recorrer às relações sociais naquelas circunstâncias e muitos dos que tiveram a chance fizeram-no. Parentes e amigos ajudavam os perseguidos mesmo discordando de suas ideias, por entender que o vínculo pessoal falava mais alto que considerações político-ideológicas.

Não é possível detalhar os casos de acomodação analisados no livro, ressaltando que foram registrados não apenas em entrevistas como também na documentação dos órgãos de informação. Vejamos sumariamente alguns exemplos, com o objetivo de esclarecer o argumento. Em algumas instituições, houve acordos para a escolha de dirigentes de universidades e entidades científicas que fossem aceitáveis tanto para a ditadura como para os meios acadêmicos. Em meio aos expurgos de docentes foram feitas negociações para evitar algumas demissões, de modo que alguns quadros esquerdistas permaneceram em seus postos. De maneira parecida, houve arranjos para permitir a contratação de docentes bloqueados pelos órgãos de informação, resultando em que o expurgo da esquerda nas instituições acadêmicas não foi completo. De modo semelhante, foram feitas negociações para evitar a punição de estudantes rebeldes, sempre com objetivo de não aumentar tensões que poderiam gerar mais protestos. Acordos também foram feitos para liberar eventos culturais e acadêmicos inicialmente proibidos, e do mesmo modo para autorizar a concessão de bolsas a pesquisadores esquerdistas. Um último exemplo, significativo: o CEBRAP (Centro Brasileiro de Análise e Planejamento), uma entidade de pesquisa fundada em 1969 por intelectuais expurgados da Universidade de São Paulo, teve a sua criação mediada por negociação com o comando militar da área.

Outro aspecto da acomodação nos meios científicos e intelectuais deve ser destacado. A ampliação do sistema universitário e das instituições de pesquisa abriu oportunidades interessantes de carreira, descortinando um horizonte de expectativas positivas. Um dos objetivos do projeto era exatamente empolgar as lideranças acadêmicas e afastá-las da contestação radical. Muitos líderes acadêmicos julgavam que seu engajamento na reforma universitária da ditadura e na ampliação de infraestrutura de pesquisa e pós-graduação se justificava em nome do interesse do país. Nessa ótica, aproveitar os investimentos do regime militar e dirigi-los para fins produtivos era percebido como forma de servir aos interesses nacionais, e não a um governo específico. Assim, inúmeros professores 


\section{Rodrigo Patto Sá Motta}

que se opunham à ditadura chefiaram departamentos universitários, laboratórios e grupos de pesquisa, e também trabalharam em assessorias e consultorias para agências oficiais como CNPq, Capes e Finep.

Ponto de vista semelhante foi adotado por algumas pessoas que aceitaram cargos na máquina do governo. Trata-se de situação realmente paradoxal: o caso de intelectuais com origem na esquerda contratados para cargos no próprio Estado autoritário. A situação é de fato estranha, pois muitos desses intelectuais ou técnicos foram perseguidos nos anos iniciais da ditadura, sofrendo demissão, às vezes prisão, tendo passaportes bloqueados e outros tipos de restrição. Quando foram contratados - ressaltando-se que não se tratava apenas de cargos de docência, mas de posições em ministérios e empresas públicas -, continuaram sob a vigilância dos órgãos de informação, que algumas vezes atacaram a "infiltração comunista" nos governos da "Revolução". 15 É realmente paradoxal que acadêmicos pertencentes ao campo esquerdista e anteriormente presos pela ditadura como José Leite Lopes, Simon Schwartzman, Hélio Pontes, José Israel Vargas, Warwick Kerr, entre outros, tenham assumido cargos oficiais em universidades e instituições de pesquisa.

A situação paradoxal, raiando a contradição, provoca duas perguntas: por que o Estado contratava pessoas que considerava do campo inimigo? Por que elas aceitavam? Pela ótica do Estado, a explicação era sobretudo o interesse em aproveitar quadros competentes e acomodá-los em posições estratégicas. Em alguns casos, os contratados não esposavam mais ideias radicais, porém, tampouco partilhavam os valores do regime militar. Do ponto de vista desses intelectuais e cientistas tratava-se de trabalhar em benefício do país, como registraram em memórias ou em entrevistas. Além disso, às vezes aceitavam cargos por perceber a natureza paradoxal da ditadura, que tinha figuras influentes não comprometidas com a máquina repressiva e mobilizadas por um projeto modernizador com rasgos "cordiais" - ou seja, mais acomodação e menos coerção. Assim, os que aceitaram posições oficiais no período da ditadura não se consideravam cúmplices de estratégia de cooptação do Estado, mas agentes sagazes que se aproveitavam dos paradoxos do regime militar para produzir ações úteis e de interesse público, como proteger colegas perseguidos ou fomentar o desenvolvimento nacional.

Aliás, desenvolvimentismo e nacionalismo serviram de ponte a aproximar intelectuais de oposição e setores do regime militar, que de fato se engajou em projeto desenvolvimentista, embora de corte elitista e autoritário, como no próprio caso da modernização universitária. Por esse caminho transitaram alguns intelectuais de oposição como a economista Maria da Conceição Tavares, que era professora de universidade federal e pesquisadora da Finep (Financiadora de Estudos e Projetos), órgão de pesquisa do governo federal. A propósito, Tavares ofereceu uma declaração interessante em entrevista publicada nos anos 1980:

${ }^{15}$ Como no episódio da lista publicada pelo Ministro do Exército general Sylvio Frota, em novembro de 1977, no contexto de disputas internas à ditadura. A referida lista continha nomes de 97 servidores públicos federais acusados de serem comunistas. 


\section{A estratégia de acomodação na ditadura brasileira e a influência da cultura política}

Veja as contradições do Estado brasileiro: você luta apoiado por estruturas do próprio Estado. ... Nós somos o único país da América Latina em que se lutou de dentro da universidade, com dinheiro do governo, contra o próprio governo. ${ }^{16}$

Referindo-se aos cargos docentes em geral e não apenas aos cargos de confiança, a declaração da professora aponta para o viés da luta contra o autoritarismo, da resistência. De fato, alguns professores e pesquisadores que trabalhavam em instituições oficiais fizeram críticas às políticas do governo e participaram de atos de resistência. Entretanto, nesse jogo havia também acomodação, já que críticas agudas e públicas poderiam gerar ações repressivas. A essa lógica estavam particularmente sujeitos os ocupantes de cargos de confiança. Mesmo que não tivessem afinidade ideológica com a ditadura, os detentores de cargos oficiais precisavam portar-se de maneira discreta, sob o risco, evidentemente, de perder a posição. Em meio a tantas ambiguidades e paradoxos, não deveria causar espanto o fato de, ainda assim, alguns dirigentes de órgãos oficiais terem usado seus cargos para ações que talvez não possam ser classificadas como de resistência, mas que, ao menos, reduziram os efeitos da repressão. Usaram a acomodação para minorar o autoritarismo ao proteger alguns alvos da repressão.

De qualquer modo, é importante não exagerar. Nem todos tiveram chance de usar meios de acomodação e nem sempre essas iniciativas geraram bons frutos. Quaisquer possibilidades de tolerância ou flexibilidade por parte de agentes do Estado repressivo estavam limitadas pela percepção da gravidade dos atos, ou da "periculosidade" das pessoas envolvidas. Assim, os suspeitos de pertencimento a grupos revolucionários eram tratados com mais rigor, sendo mais difícil estabelecer arranjos para livrá-los. Os casos de professores detidos por mais tempo, sobretudo os que sofreram tortura, em geral envolviam suspeita de participação em (ou apoio a) grupos revolucionários clandestinos. Importante lembrar também que o aparato repressivo assassinou ao menos cinco docentes universitários, entre eles Ana Rosa Kucinski, Vladimir Herzog e Lincoln Bicalho Roque, além de dezenas de estudantes, na maioria militantes dos grupos revolucionários.

Mas, o exercício constante da violência, inclusive com tortura e assassinatos, não muda o fato de que a ditadura também utilizou (ou permitiu que fossem utilizados) estratégias de acomodação para manter o seu poder. Levar em conta essa outra faceta é necessário para um quadro mais completo da história da ditadura, assim como para entender dilemas presentes até hoje.

16 Disponível em: http://www.canalciencia.ibict.br/notaveis/txt.php?id=38. $\quad$ [Consulta:
17/05/2011]. 


\section{Rodrigo Patto Sá Motta}

A acomodação na ditadura teve efeitos paradoxais, que permanecem sujeitos a dúvida e debate polêmico. Vale a pena destacar a utilidade do conceito acomodação no lugar de outras opções disponíveis, como cooptação, que sugere um sentido mais pejorativo. Esses intelectuais e cientistas não foram meramente cooptados, não aderiram à ditadura nem se colocaram a serviço da máquina repressiva. E algumas vezes usaram seus cargos ou seus contatos para proteger pessoas perseguidas pelas forças da repressão, contribuindo para a manutenção de alguns intelectuais de esquerda nas instituições acadêmicas e científicas. A propósito, devido a tal flexibilidade foram contratados profissionais de outras partes da América Latina que fugiam da repressão em seus países. Também por aí se explica porque foi permitida a circulação limitada de valores inspirados na esquerda, inclusive alguns textos de K. Marx, cuja obra não foi objeto de censura oficial. ${ }^{17}$ Com isso, apesar dos esforços da repressão, as ideias de esquerda se disseminaram nas universidades durante os anos da ditadura. No fim do processo elas eram mais influentes do que haviam sido antes do golpe de 1964, embora o comunismo estivesse em crise e superado por "novas esquerdas", e o marxismo fosse consumido pelos jovens em doses superficiais.

Porém, fica a dúvida sobre o resultado final da acomodação, pois, apesar de algumas derrotas da ditadura na batalha das ideias, tais ações não necessariamente enfraqueceram o Estado autoritário. A acomodação certamente atrapalhou e minou o poder da ala radical da ditadura que, por isso, não conseguiu fazer o expurgo completo de seus inimigos. Entretanto, ao mesmo tempo, as estratégias de acomodação tornaram mais suave para o Estado a gestão do mundo acadêmico, na medida em que reduziram as tensões. Os jogos sutis de acomodação fortaleceram a banda moderada da ditadura, mas não debilitaram o regime autoritário como um todo. Em outras palavras, eles podem ter contribuído para atenuar o autoritarismo e incentivar o lado moderado da ditadura. Mas, se de um lado isso reduzia a violência, de outro aumentava as chances de um duradouro regime autoritário, ainda que menos sangrento em comparação com seus vizinhos. A estratégia de acomodação não necessariamente abreviou o retorno à democracia. Pode ter gerado o contrário, ou seja, um regime autoritário mais duradouro.

Outro desdobramento negativo desse processo foi facilitar para os líderes da ditadura negociar uma saída suave do poder. Não é à toa que o Brasil é o único país do cone sul sem processos de investigação criminal contra os agentes da ditadura. Há um elevado grau de adesão aos acordos suaves, à bizarra ideia de anistia como perdão recíproco - consubstanciada na lei de anistia de 1979, ainda em vigor. Com base na análise desenvolvida nestas páginas é possível afirmar que

\footnotetext{
17 A censura proibiu obras de marxistas revolucionários, como Lenin, Mao e Guevara, mas não os livros do próprio K. Marx (que teve alguns textos vendidos em bancas de revista a partir de 1974). 0 discurso oficial era anticomunista, mas não necessariamente antimarxista, entre outras razões porque não se pretendia ferir a sensibilidade de aliados liberais e para não oferecer uma prova cabal de que havia censura à liberdade de pensamento.
} 


\section{A estratégia de acomodação na ditadura brasileira e a influência da cultura política}

a disposição de aceitar a acomodação pós-ditadura foi influenciada pelos jogos de acomodação permitidos durante a ditadura, que envolveram não apenas as elites acadêmicas e culturais, como também parte das lideranças políticas.

Fundamental, portanto, perceber que a acomodação serviu para reduzir os conflitos durante a ditadura. Um fenômeno inscrito na cultura política, mas também uma opção dos agentes estatais e sociais em ação no contexto. A pesquisa que gerou o livro teve como foco central as elites acadêmico-científicas, mas, vale a pena investigar a possibilidade de incluir no mesmo escopo teórico outros grupos sociais que se acomodaram à ditadura, como os produtores culturais e artistas e mesmo as elites políticas tradicionais. Tal linha de análise é importante por oferecer compreensão menos dicotômica da ditadura, mais abrangente. Também porque ajuda a entender os impasses da transição pós-autoritária e as dificuldades para superar inteiramente a ditadura, o que implicaria julgar os crimes e seus autores, identificando claramente os responsáveis.

Porém, e retomando a análise sobre a historiografia dedicada à Europa nazista, há que ter cuidado com os riscos do exagero. A crítica contra visões simplistas e dicotômicas não deve recair no mesmo erro, ainda que em direção oposta. Em outras palavras, ao mostrar a importância da acomodação o propósito não é relegar a segundo plano as ações de resistência. Nem todos aderiram à ditadura, nem todos se acomodaram, muitos atores lutaram contra o Estado autoritário utilizando-se de diferentes meios. Indispensável analisar de maneira equilibrada tais fenômenos - tão complexos como polêmicos -, com atenção também para as mudanças ao longo do tempo, em que ocorreram oscilações na intensidade das ações de resistência, de adesão e/ou de acomodação com a ditadura, e também no comportamento de muitos atores.

No caso do Brasil, ademais, é importante considerar que largas faixas da população mostraram-se indiferentes ou alheias aos grandes embates políticos, o que corresponde a situação de tradicional exclusão política. Para além da exclusão social e da pobreza extrema, e muitas vezes em combinação com tais fenômenos, existe a exclusão política de grupos sociais marginalizados da cidadania, inclusive do direito ao voto. Vale a pena lembrar que os analfabetos só conquistaram o direito ao voto no Brasil em 1988. Aliás, a estratégia de acomodação e a tentativa de evitar conflitos políticos graves respondia exatamente ao desejo de não atrair para o cenário político esses setores populares excluídos. Assim, para uma análise adequada dos comportamentos sociais diante da ditadura, há que considerar não apenas os que aderiram, resistiram e/ou se acomodaram, mas também os indiferentes e os excluídos.

Não poderia concluir este artigo sem mencionar o momento de grave crise política no Brasil, que traz à tona os impasses da cultura política e o risco de novo 


\section{Rodrigo Patto Sá Motta}

surto autoritário. 0 país encontra-se diante de conflitos semelhantes aos vividos em anos passados, com suas instituições democráticas mostrando-se mais frágeis do que nunca. Uma crise que consterna tanto mais porque encerrou um período positivo, em que tivemos crescimento econômico com redução das desigualdades sociais, sob o comando dos governos petistas. No entanto, para ter sucesso, o projeto de poder do PT e Lula se rendeu à tradição política brasileira, depois de alguns anos tentando mudar as coisas por meio de combate frontal. Perceberam a fraca disposição da maioria para apoiar soluções radicais e também as possibilidades de utilizar o personalismo em favor do projeto de esquerda. Decidiram, pois, render-se à cultura e às tradições políticas para ter chances de ganhar as eleições, e para ter meios de governar depois da vitória eleitoral. Protagonizaram, assim, mais um episódio de conciliação/acomodação. Como tem sido comum na história brasileira, o governo de Lula iniciou um processo de mudanças ambíguo, uma espécie de modernização conservadora, mas com a novidade de possuir um viés de esquerda.

A estratégia da acomodação tem servido historicamente para preservar a ordem e evitar rupturas sociais, como foi mostrado. Mas, também pode servir para abrir caminho a projetos de mudanças lentas, ainda que isso signifique assumir certos riscos. Foi esse o caminho tentado pelos governos petistas, ao aceitarem arranjo que integrou setores conservadores ao governo de esquerda e manteve (ou reforçou) os piores aspectos do sistema político brasileiro. Entretanto, fizeram-no como uma pré-condição para chegar ao poder e realizar as almejadas mudanças sociais. Protagonizaram uma acomodação com segmentos da classe dominante, porém, com o objetivo de gerar a inclusão social, embora lentamente. E, de fato, os governos petistas impulsionaram parte da agenda de mudanças sociais, apesar dos seus sócios conservadores.

Se considerarmos que a política é a arte do possível, ou se evocarmos a ética da responsabilidade de Max Weber, o projeto lulista é compreensível e até aceitável. E por muito tempo pareceu funcionar perfeitamente, trazendo benefícios aos mais pobres e implantando políticas sociais, educacionais e culturais avançadas. Mas faltou algo aí. Se pretendia realmente manter-se fiel à ideia de mudanças, o projeto não poderia ter se acomodado inteiramente ao sistema político, à velha cultura política. Claro que não é fácil mudar tradições arraigadas. Mas para que serve um partido de esquerda? Haveria que tentar! Faltou uma estratégia para mudar o sistema político tradicional, que as lideranças petistas parecem ter acreditado poder controlar para sempre, à base de fisiologismo e corrupção. Há uma responsabilidade grave do PT nesse ponto: imaginando-se o único partido decente e representativo do povo, preferiu manter o apoio dos outros com base na corrupção, desistindo da possibilidade de melhorar o sistema partidário. Uma democracia pluralista precisa de partidos representativos, consistentes, e parece que os governos petistas contribuíram para piorar o quadro. Ao privilegiar laços baseados na corrupção o governo montou base de apoio frágil 


\section{A estratégia de acomodação na ditadura brasileira e a influência da cultura política}

e cavou sua sepultura, pois os "aliados" abandonaram o barco rapidamente na hora da crise, já que não estavam ali devido a outras convicções.

A conciliação que estava na base dos governos petistas ruiu. Em meio a essa derrocada política o país ficou dividido entre favoráveis e contrários ao impeachment de Dilma Rousseff, polarização que em muitos casos se combinou com o confronto direita x esquerda. Nos meses iniciais de 2016 viu-se o aumento espetacular dos protestos de rua, tanto de um lado como do outro do espectro ideológico. E aprofundou-se o aumento da influência dos valores direitistas, especialmente entre a classe média, uma tendência que já vinha se desenhando nos últimos anos.

Nesse quadro de polarização e radicalização, chegou-se a imaginar que a campanha pelo impeachment de Dilma Rousseff terminaria levando a confrontos violentos. Em especial porque muitos cidadãos, notadamente os mais jovens, vinham mostrando indisposição para acordos. Por isso, talvez essa crise venha a ser um marco, uma quebra de paradigmas no que toca aos comportamentos e valores políticos. Ela terá força para gerar uma nova cultura política? Estamos presenciando a formação de uma cidadania mais envolvida com as lutas políticas, mais visceral, mais conflitiva? Menos tolerante com estratégias de acomodação? Será o fim da tradicional conciliação brasileira?

É muito cedo para responder a tais questões. Além do mais, o próprio processo de impeachment resultou de grande conciliação, que envolveu a maioria da elite política (uma parte da qual virou às costas repentinamente ao ex-aliado PT), as grandes empresas de mídia, o sistema judiciário e as corporações empresariais. Todos esses grupos aceitaram que a Constituição fosse manipulada para permitir a retirada de Rousseff do poder, pois fingiram acreditar na tese de que ela cometeu crime de responsabilidade. Além disso, a persistência da estratégia de acomodação aparece em algumas tentativas do governo de Michel Temer para arrefecer os ânimos da oposição, com base na reiteração do discurso tradicional de que os brasileiros não são dados ao ódio político. Além do discurso, alguns gestos do novo governo indicam a tentativa de acomodar-se com setores da oposição. Acordos parecidos aos que vimos sob a ditadura ocorrem hoje na área da cultura e na gestão de algumas entidades científicas, com líderes aceitando trabalhar para um governo espúrio em nome de interesses maiores.

Veremos em breve se começou no Brasil uma fase de conflitos políticos mais intensos ou se os ânimos vão ser arrefecidos por meio de novas conciliações. Tomara que não! Pois a acomodação significa reduzir os confrontos, mas também postergar a solução dos problemas. Além disso, no presente momento ela interessa especialmente à consolidação do governo de Michel Temer, que é fruto de um espúrio processo de impeachment. 


\section{Rodrigo Patto Sá Motta}

\section{Bibliografia}

André Singer. Sentidos do Lulismo. Reforma gradual e pacto conservador. São Paulo, Companhia das Letras, 2012.

Daniel Aarão Reis Filho. "Ditadura e sociedade: as reconstruções da memória"em Daniel Aarão Reis Filho, Marcelo Ridenti, Rodrigo Patto Sá Motta (org.). O golpe e a ditadura militar: quarenta anos depois (1964-2004). Bauru, Edusc, 2004.

Daniel Aarão Reis Filho. Ditadura militar, esquerdas e sociedade. Rio de Janeiro, Zahar, 2000.

Denise Rollemberg. "As trincheiras da memória. A Associação Brasileira de Imprensa e a ditadura (1964-1974)", em Denise Rollemberg e Samantha Quadrat (org.). A construção social dos regimes autoritários: legitimidade, consenso e consentimento no século XX. Rio de Janeiro, Civilização Brasileira, 2010.

Denise Rollemberge Samantha Quadrat (org.). A construção social dos regimes autoritários: legitimidade, consenso e consentimento no século XX. Rio de Janeiro, Civilização Brasileira, 2010.

Francisco José de Oliveira Vianna. Instituições políticas brasileiras. São Paulo, José Olympio, 1949.

Gilberto Freyre. Ordem e progresso. Rio de Janeiro, José Olympio, 1959.

Henry Rousso. Le Syndrome de Vichy. Paris, ÉditionsduSeuil, 1987.

Jacques Semelin. Sans armes face à Hitler, la resistance civileen Europe. Payotet Rivages, 1989.

Jose Honório Rodrigues. Conciliação e reforma no Brasil: um desafio histórico-cultural. Rio de Janeiro, Nova Fronteira, 1965.

Marcelo Ridenti. "Resistência e mistificação da resistência armada contra a ditadura: armadilhas para os pesquisadores" em Daniel Aarão Reis Filho, Marcelo Ridenti, Rodrigo Patto Sá Motta (org.). O golpe e a ditadura militar: quarenta anos depois (19642004). Bauru, Edusc, 2004.

Philippe Burrin. La France à l'heure allemande: 1940-1944. Paris, Éditions du Seuil, 1995.

Pierre Laborie. L'Opinionfrançaise sous Vichy. Paris, Éditions du Seuil, 1989.

Roberto Da Matta. A casa \& a rua. 5a ed. Rio de Janeiro, Rocco, 1997.

Robert Paxton. La France de Vichy, 1940-44. Paris, ÉditionsduSeuil, 1974.

Rodrigo Patto Sá Motta. (org.). Ditaduras militares: Brasil, Argentina, Chile e Uruguai. Belo Horizonte, Editora da UFMG, 2015.

Rodrigo Patto Sá Motta. "O golpe de 1964 e a ditadura nas pesquisas de opinião". Revista Tempo, vol. 20, Niterói, 2014, pp.1-21.

Rodrigo Patto Sá Motta. As universidades e o regime militar. Cultura política brasileira e modernização autoritária. Rio de Janeiro, Jorge Zahar, 2014.

Sérgio Buarque de Holanda. Raízes do Brasil. 26a ed. São Paulo, Companhia das Letras, 1995.

Sérgio Miceli. Intelectuais à brasileira. São Paulo, Companhia das Letras, 2001.

Recibido: 28/05/2016

Evaluado: $27 / 06 / 2016$

Versión Final: 24/07/2016 